\title{
The Effects of Prohibiting Smoking in Public Places in Cabanatuan City
}

\section{Mary Chris Austria-Cruz}

Nueva Ecija University of Science and Technology, Philippines

maria_cristi@yahoo.com

\begin{abstract}
The research conducted to know the effects of prohibiting smoking in public places in Cabanatuan City on the users of cigarettes in Cabanatuan Terminal, Cabanatuan Market and in Nueva Ecija University of Science and Technology (NEUST) Campuses. The question serves as an instrument to gather the needed information to sustain the problem stated. The profile of the respondents also asked to complete the data needed. Statistical treatment was used to get the percentage of the question. Based from the data gathered, the researchers drawn conclusions regarding to the effects of prohibiting smoking in public places in Cabanatuan City on the users of cigarettes of Cabanatuan Terminal, Cabanatuan Market and NEUST Campuses. The main cause of smoking is weak legislation cause users of cigarette. On the result of the effects of smoking is air pollution and it is one of the major causes of global warming. Therefore, the researchers formulated the following recommendation based on the smoker's responses: there should be a strict implementation of the rules and regulations to avoid smoking and at the same time to lessen a person smoking in public places; there should be an increase of tax of cigarette to lessen the buyers; and the government should add more police officer to secure the public places if there's anyone who violates the law about smoking ban.
\end{abstract}

Keywords - Smoking, Weak Legislation, Rules and Regulations, Cigarette, Smoking Ban.

\section{INTRODUCTION}

The growing number of countries, states / provinces / territories and cities around the world that have or are preparing to enact extensive smoke-free policies represents a global shift toward smoke-free public places and workplaces. (Griffith et al., 2008)

According to Tobacco Regulation Act of 2003, smoking refers to the act of carrying inhaled or smoked a lighted cigarette or other tobacco products. On the contrary, Deluna and Maneja (2015) concluded that depending on the respondents ' interpretation, the anti-smoking media campaign did not affect the respondents ' smoking conduct. Thus, Mojares et al. (2012) recommended that authorities should be able to devise effective ways of identifying the precise boundaries protected by the Order.

According to the result of 2009 Global Adult Tobacco Survey (GATS), almost half of adult males and females are current smokers. Moreover, twenty three percent $(23 \%)$ of Filipino adults are daily tobacco smokers; Thirty eight percent $(38 \%)$ for males and seven percent $(7 \%)$ for females. Male daily smokers consume 11 cigarettes per day while female daily smokers consume seven (7) cigarettes per day.
Alechnowicz and Chapman (2004) stated that the Philippines was the fifteenth largest consumer of tobacco products and actually has one of Asia's highest smoking rates and some of the lowest smoking rates prices. Stated by Geronimo (2017), the Department of Health $(\mathrm{DOH})$ said "scare tactics seem to have work well among the Filipino working population". The Philippine said "made progress in protecting the public from exposure to second hand smoke."

Das (2003) concluded that there are several carcinogens in cigarette smoke that change biochemical defense systems and contribute to lung cancer. Fichtenberg and Glance (2002) added that in shielding non-smokers from passive smoking, smoke-free workplaces often allow smokers to quit or reduce their intake.

In the City of Cabanatuan, most of men are smoking in public places that can cause accident and it is not good for the health of the person smoking and most of all to a person who are second-hand smoker. 


\section{OBJECTIVES OF THE STUDY}

The study attempted to describe the possible causes of smoking in Cabanatuan City and the possible effects of prohibiting cigarette smoking in Cabanatuan City.

\section{METHODOLOGY}

The descriptive method of research was used in this study because it involves description, recording, analysis and interpretation of condition that really exists. It is appropriate to use descriptive method in gathering information about the present existing condition (Creswell, 2014). Also, Weighted Mean, Relative Important Index and Ranking were used as statistical treatment as basis of analysis for the gathered information

\section{RESULTS}

Table 1 shows the rating of the items under weak legislation implementation as perceived by all of the respondents. The table above shows that Q5 (Does weak legislation cause users of cigarette?) got the highest mean among the items with 3.81 total weighted mean and verbally interpreted as OFTEN /AGREE. On the other hand, Q3(Do police officers' negligence cause smoking in public?)got the lowest mean with 2.04 total weighted mean and verbally interpreted as RARE/DISAGREE.

Table 1. Causes of Smoking

\begin{tabular}{|l|c|}
\hline \multicolumn{1}{|c|}{ ITEM STATEMENT } & $\begin{array}{c}\text { WEIGHTED } \\
\text { MEAN }\end{array}$ \\
\hline $\begin{array}{l}\text { Q1. Do street vendors mistake cause } \\
\text { many people smoke in public places? }\end{array}$ & 3.56 \\
\hline $\begin{array}{l}\text { Q2. Do smokers in public places cause } \\
\text { second-hand smoker? }\end{array}$ & 3.80 \\
\hline $\begin{array}{l}\text { Q3. Do police officers' negligence } \\
\text { cause smoking in publics? }\end{array}$ & 2.04 \\
\hline $\begin{array}{l}\text { Q4. Does weak implementation cause } \\
\text { violation in smoking ban? }\end{array}$ & 3.04 \\
\hline $\begin{array}{l}\text { Q5. Does weak legislation cause users } \\
\text { of cigarette? }\end{array}$ & 3.81 \\
\hline \multicolumn{1}{|c|}{ TOTAL WEIGHTED MEAN } & $\mathbf{3 . 8 7}$ \\
\hline
\end{tabular}

Table 2. Effects of Smoking

\begin{tabular}{|l|c|c|}
\hline \multicolumn{1}{|c|}{ ITEM STATEMENT } & RII & RANKING \\
\hline $\begin{array}{l}\text { Do you think smoking should be } \\
\text { banned? }\end{array}$ & 0.06 & 4 \\
\hline $\begin{array}{l}\text { Do you think that passive smoking } \\
\text { kills millions of people per year? }\end{array}$ & 0.07 & 3 \\
\hline
\end{tabular}

\begin{tabular}{|l|c|c|}
\hline $\begin{array}{l}\text { Do you think smoking can cause air } \\
\text { pollution? }\end{array}$ & 0.1 & 1 \\
\hline $\begin{array}{l}\text { Do you think smoking is the main } \\
\text { reason for vehicle accidents? }\end{array}$ & 0.08 & 2 \\
\hline $\begin{array}{l}\text { Do you think smoking is one of the } \\
\text { major causes of global warming? }\end{array}$ & 0.08 & 2 \\
\hline $\begin{array}{l}\text { Do you think smoking can relieve } \\
\text { your stress? }\end{array}$ & 0.08 & 2 \\
\hline $\begin{array}{l}\text { Do you think smoking is good to } \\
\text { your health? }\end{array}$ & 0.04 & 5 \\
\hline $\begin{array}{l}\text { Do you think the youth follow the } \\
\text { rules of smoking ban in public } \\
\text { places? }\end{array}$ & 0.06 & 4 \\
\hline Does smoking cause restlessness? & 0.08 & 2 \\
\hline $\begin{array}{l}\text { Do you think smoking is expensive } \\
\text { vise? }\end{array}$ & 0.07 & 3 \\
\hline
\end{tabular}

Table shows the rating of the items under the effects of prohibitingas perceived by the worker-respondents. The table above shows that Q3 (Do you think smoking can cause air pollution?) got the highest RII (Relative Important Index) among the items with 0.1. On the other hand, Q1 (Do you think smoking should be banned?) and Q8 (Do you think the youth follow the rules of smoking ban in public places?) got the lowest RII (Relative Important Index) with 0.06.

\section{CONCLUSION AND DISCUSSION}

Based on the above findings of the study, the findings were the main cause of smoking is "Weak Legislation Implementation." There should be a strict implementation of the rules and regulations to avoid smoking and at the same time to lessen a person smoking in public places and an increase of tax of cigarette to lessen the buyers. On the result of the effects of smokingis air pollution and it is one of the major causes of global warming.

\section{REFERENCES}

[1] Alechnowicz, K., \& Chapman, S. (2004). The Philippine tobacco industry:"the strongest tobacco lobby in Asia”. Tobacco Control, 13(suppl 2), ii71-ii78.

[2] Creswell, J. W. (2014). A concise introduction to mixed methods research. SAGE publications.

[3] Das, S. K. (2003). Harmful health effects of cigarette smoking. Molecular and cellular biochemistry, 253(1-2), 159165. 
[4] Deluna, R. (2015). The Effect of Sin Tax and Anti-Smoking Campaign in Regulating Cigarette Smokers in Davao City, Philippines.

[5] Global Adult Tabacco Survey (2009). 2009 report of Global Adult Tabacco Survey. Retrieved from: https://psa.gov.ph/content/173-million-filipino-adults-arecurrent-tobacco-smokers-final-results-2009-global-adult

[6] Geronimo (2017). Fewer Filipino adult smokers in 2015 survey. Rappler News. Retrieved from: https://www.rappler.com/nation/169052-2015-gats-resultsphilippines

[7] Griffith, G., Welch, C., Cardone, A., \&Valdemoro, A. (2008). The global momentum for smokefree public places: best practice in current and forthcoming smokefree policies. Saludpublica de Mexico, 50(S3), 299-308.

[8] Government of the Philippines (2003). Republic Act No. 9211.An Act Regulating The Packaging, Use, Sale, Distribution And Advertisements Of Tobacco Products And For Other Purposes. Retrieved from: https://www.officialgazette.gov.ph/2003/06/23/republic-act$\underline{\text { no-9211/ }}$

[9] Fichtenberg, C. M., \&Glantz, S. A. (2002). Effect of smokefree workplaces on smoking behaviour: systematic review. Bmj, 325(7357), 188.

[10] Mojares, R. E., Macuha, F. C., Casala, J. G., Morales, D. P., Catapang, C. G., \& Perez, K. F. (2014). Awareness on the Implementation of Anti-Smoking Ordinance No. 1S. 2012. Asia Pacific Journal of Multidisciplinary Research| Vol, 2(5). 